\title{
Recent Trends in the Geography of Religion in Japan
}

\author{
MATSUI Keisuke \\ Graduate School of Life and Environmental Sciences, University of Tsukuba, \\ Tsukuba 305-8572, Japan
}

\begin{abstract}
This study examines the recent trends in the geography of religion by Japanese geographers since the 1990s. The geographers of religion in Japan mainly analyze and interpret the distribution or diffusion of religious phenomena including religious experience or practice, spatial structure of religion, and religious landscape. I was able to summarize the studies in this field into the following four types. The studies of the first type focus on how certain religions have been practiced in urban or rural areas. The studies of the second type examine the influences, roles and changes of religions in urban and rural communities and their landscape. The studies of the third category encompass achievements of religious ecology and relationship between religions and natural environment. The forth type of studies are historical geography of pilgrimage which have revealed socioeconomic network produced by religion. Three directions of future studies are suggested. First, the geography of religion should contribute more to the elucidation of the religion. Second, achievements of this study field are requested to correspond to the religious situations of contemporary Japan. Third, studies taking the religious characteristics of Japan into consideration are needed.
\end{abstract}

Key words: geography of religion, religious landscape, religious ecology, pilgrimage

\section{Introduction}

We can say that the simple definition of the geography of religion is to clarify some spatial characteristics of religion. If we consider a religious phenomenon to be a part of culture created by human beings, the geography of religion can be classified as a branch of cultural geography. However, if the religious phenomenon has also political, economic, social and psychological aspects, we cannot limit it to the framework of cultural geography.

On the other hand, the geography of religion exists as a subfield of religious studies. Inoue (2002) has classified religious studies into the following two types. One argues about religious essence; the philosophy and phenomenology of religion are classified into this type. The other is based on an actual phenomenon; the history of religion, psychology of religion and sociology of religion are included in this. The geography of religion should be classified into the latter. However, the geography of religion has been considered relatively less important in religious stud- ies. For instance, Inoue (2002) comments ironically "There is a field called the geography of religion, which has few researchers in Japan." Ishida (1989) also gives a negative evaluation in his review paper, "...geography of religion is the subfield of religious studies which aims to clarify the correlation of religion and natural environment." Ishida (1989) also states that the geography of religion had complemented other religious studies, and said "An understanding of religion will turn more positive by clarifying the relation between natural conditions and religion." Researchers of religion seemed to have considered that the geographical features are not an essential element for a religious phenomenon. Therefore, the geography of religion is positioned as an auxiliary study of religious studies.

There have been many publications in recent years by Japanese geographers. In my previous papers on the geography of religion in Japan (Matsui 1993: 2003), I classified studies of this field into the following four: 1) climate and natural environment, 2) cultural landscape and religion, 3) pilgrimage, and 4) the distribution / diffusion and spatial structure of religion. Although 
I think this framework is fundamentally effective, as also indicated by Oda (2002), the time to reexamine a new framework is approaching. Thus, the purpose of this paper is to describe the trends of geographical studies on religion by Japanese geographers after the 1990s and to comment on the future prospects of the geography of religion during the next 10 years.

\section{Current Topics of the Geography of Religion in Japan}

In describing publications that have appeared in print during the past 10 years, I would like to introduce four books. In terms of writings that deal with the place of public worship, there are two notable books; the "Zonal Structure of Dewa Mountains" by Iwahana, M. and "Religious Space in Japan" by Matsui, K. Iwahana (2003) compiles his previous researches of the Dewa Mountain faith into a book. He showed that the catchment area of Dewa Mountain faith consists of a threeconcentric-circle structure. The inner most area, called a sacred area, is surrounding the top of the mountains. The next area, called a semi- sacred area, is located around the first one. The outer area is the residential area of the believers. He demonstrated that the characteristics of each area are based on abundant folklore data. Matsui (2003) tried to clarify the regional difference in the mode of people's belief in the popular religion instead of mountainous religion, which has been thoroughly studied. While mountainous religion has a distinct spatial structure, popular religion like Inari faith and thunder faith that Matsui investigated is not clear in the work of propagators. Thus it is difficult to point out the characteristics of the worship catchment area for them.

There are two important books in the field of pilgrimage studies; "Pilgrims and routes around sacred place" by Tanaka, T. and "Modern times of the Shikoku pilgrimage" by Mori, M. Tanaka (2004) was published posthumously. His works have two features; the decisions involved in creating pilgrimage routes, and the detailed descriptions of the actual mode of pilgrimage using the travelers' journals (diaries). In particular, his important literatures of the Saikoku pilgrimage are included in this book. Whereas Tanaka's study was conducted by using historical geography methods, Mori (2005a) approached the Shikoku pilgrimage from the viewpoint of cultural geography. He argued that the Shikoku pilgrimage was reconstructed in the hundred years since the Meiji Restoration. We can say that his book reflected upon the Shikoku pilgrimage, a cultural phenomenon, from the position of a social constructionist.

Reflecting this trend, the "Historical Geography of Religious Culture" was argued as a topic in the Annual Conference of the Association of Historical Geographers in Japan held in 2003 and 2004. The result of the discussions was published in the journal of "The Historical Geography", which contains five articles on pilgrimage organization (Ise-ko) in the community, worship catchment areas of religions, pictorial maps, feng shui, and cemeteries. Thus the theme of geographical study on religion is increasing, especially in the field of historical geography.

We can consider that these topics are the typical subject of this field among contemporary Japanese geographers. The growth of literature is also remarkable in terms of the increasing number of review papers. Although Taima (1961) and Matsui (1993) appeared before 1995, many excellent review papers have been published in recent years.

Oda $(1999 a, 2002)$ are examples of review papers. Oda (2002) reviewed the studies on the geography of religion by using a "Bibliography in Geography" edited by the Human Geographical Society of Japan as data. He indicated the research trend of the geography of religion in Japan after World War II. Oda (2002) pointed out the following seven subjects of research, 1) religious cities/settlement, 2) pilgrimages, 3) grave systems, 4) religious distribution/catchment area of religion, 5) organization of religion in urban and rural areas, 6) pictorial maps depicting sacred phenomena, and 7) mountain sanctuaries. He showed that research is increasing in the following fields: pilgrimages, grave systems, religious distribution/catchment area of religion, pictorial maps depicting sacred phenomena, and mountain sanctuaries. Moreover, Hisatake (2000) has mentioned cosmology, ethnicity and the representation of culture as a new trend of cultural geography in Japan. There have been several 
publications related to Oda's themes above. In terms of pilgrimages, Iwahana (2000) described the history of research on pre-modern trips, and discussed the pilgrimage to sacred places from the viewpoint of the exchange between the sacred and the profane. Kaneko (1995) demonstrated that there was a research trend of mountain religions from the viewpoint of their catchment areas. Matsui (1998) has also examined the catchment area of various beliefs. In terms of pictorial maps depicting sacred phenomena, Iwahana (1997) reviewed the studies of mandala pictures of Mt. Tateyama, one of the sacred mountains in the Chubu Area. Based on these achievements, I classified a research trend in this field into four themes, including 1) distribution/diffusion of religion and its spatial structure, 2) cultural landscape and social groups, 3) religion and climate/natural environment, 4) pilgrimage, tourism and sacred place. According to this classification, I would like to examine research trends in the geography of religion in Japan.

\section{Studies on the Distribution/Diffusion of Religion and its Spatial Structure}

Oda (2005) indicated that the distribution/diffusion of religion are one of the most traditional themes in this field. Both distribution and diffusion of religion are so closely related that we should understand where and how some religions are distributed through analyzing the process of diffusion.

There is an accumulation of research in this field, especially by historical geographers. Publications by Miki (1996, 1998, 2001, 2005) have examined the development of religious organization (kou) of Mt. Mitsumine in Edo (Tokyo) and Chichibu Area, and its regional acceptance. Miki (1996) argues that the religious association of Mt. Mitsumine in Chichibu Area in the latter half of Edo Era connoted the faith in various Gods, and it could be characterized as a branch of some faiths in that region. Miki (1996) explained its process of penetration after the latter half of the $17^{\text {th }}$ century in the Chichibu Area by focusing on other reasons such as the socio-economic condition of the area and the communication with neighborhood areas. Otaki Village prospered by producing lumber for Edo at that time. Therefore Mt. Mitsumine functioned as a tutelary mountain (Chinju) in that region. Miki assumed that the development and acceptance of the association of Mt. Mitsumine can be explained by the progress of manufacturing and the circulation of lumber in that region. Miki (1998) considered the relationship between existent religious groups and other reasons above. He also dealt with the association of Mt. Mitsumine in terms of faith, which was accepted by people in the region.

Focusing on the acceptance of faith in neighborhood areas, I should mention the contribution of a series of papers by Funasugi (1994, 1997). Funasugi (1997) examined the regional penetration of the Ise faith in Echigo during the Era of Sengoku (Provincial Wars). He explained the penetration of Ise faith in Japan by focusing on the relationship between the distributions of amulets (onshi) and guide priests (douja). Funasugi (1994) showed the penetration of Ise faith in the other region of the new frontier villages in Chichibu Area. He emphasized the importance of the viewpoint of seeing the relationship between community and faith from the region.

From other viewpoints, Fujimura (2001) showed the process of how foreign religions make roots. He examined the process from the relationship between the new and existent religions in the Okukumano Area. Takemura (2000) argues that the distribution and acceptance forms of the Mormon faith from the relationship with existent religions such as Jodoshinsyu sect of Buddhism. Both Fujimura and Takemura focused on the coexistence and competition of some religions in an area. They showed the necessary conditions needed for some foreign religions to take root.

For the mountainous religion, I have to refer to contributions by Sakano, Y., Hiromoto, S. and Tsutsui, Y. Sakano (2003) described the distribution and diffusion process of mountainous faith of Mt. Hakkaisan in Niigata. He pointed out two factors involved in the diffusion; the influence of the Mt. Kiso-Ontake faith and the road traffic system. We should evaluate his suggestion in his paper of a hierarchy among the sacred mountains in Japan. Hiromoto (2004) showed 
the distribution of the belief in two mountains, Hakuyu and Takayu in Tochigi, and its historical transition. Tsutsui (2004) investigated some religious groups of Mt. Chokai (Chokai-ko) in Yamagata to clarify the reason why shrines founded new believers' groups and how Shinto priests created these new groups. Her study made clear that the main reason was to get enough financial support in order to reconstruct and repair construction of the shrine.

Matsui (1995a, 1999) examined the regional characteristics of the catchment areas of religious faith through case studies of Kanamura Betsurai shrine and Kasama Inari shrine. There were some arguments to suggested a concentriccircle structure in the catchment area of religious faith. However, there were not enough papers which analyzed the areal difference among the catchment areas. Matsui (1999) described the spatial difference between neighborhood areas (the first area) and the outer areas (the second area). He explained the difference of how beliefs are accepted in an area, and the relationship with other religions. There are some case studies which treat mountainous religions such as those of Mt. Iwaki (Kaneko 1998), Mt. Taihei (Tsutsui 1999), Mt. Chokai (Tsutsui 2001). They focused on the distribution of religious groups (kou) and the customary visit to sacred places, and described the reasons for spatial differences among the catchment areas of religious beliefs.

As mentioned before, there have been many studies on religious distribution and diffusion. However, the distribution of religions across the Japan has not received much attention by geographers.

Oda (1999b) described the distribution of Christians in Japan. He showed spatial patterns and the difference in the distribution of Catholics and Protestants by counting the number of believers. Catholics were densely located in $\mathrm{Na}$ gasaki followed by Tokyo, while many Protestants inhabited Tokyo. Oda $(2003,2006)$ also analyzed the distribution of Buddhism in Japan, and showed us some geographical maps classified by the Buddhist denomination groups. He divided the whole area into seven denominational regions by using several kinds of historic statistics from temples, not by the distribution of be- lievers. He made a regional classification for the years of 1888, 1922, 1937 and 1959. Some changes in the predominant denomination were shown in these maps. Tagami (2002) classified 32 kinds of shrines into six areas using cluster analysis. The areas were all of Japan, centralpart, inland, Kanto, Chugoku and Kyusyu. He mapped out some of the distribution of shrines by type. These maps are not only important but also convenient for researchers to know the distribution of religions in Japan on macro scale.

\section{Studies about Cultural Landscapes and Social Groups}

Religious social groups are important components in communities to create the cultural landscape of religion. Therefore many researchers have paid attention to religious social groups such as Kou-groups, Danto-groups and Ujikogroups (Fujimura 2001). Imamoto (2000) described the functions of Kou-groups in rural communities. Yagi (1998) examines research from the 1980's and described the symbolism of village borders and its meanings as a place, and the importance of village cemeteries. Otsuka (1997) described the hierarchy of the belief of the people living in Suwa communities. Imazato (1995) described the social functions of religious landscapes by showing the relationship between religious facilities and the social groups that manage these facilities. Decoding religious landscapes is also an important theme. However, such articles are limited to the decoding of religious paintings.

As for the theme of social change, I should mention Sakano (2006) and Fujimura (2004). The former considered the acceptance of religion by a local community by analyzing the conversion to Catholicism in postwar Japan. He pointed out how the conversion proceeded, focusing on regional difference, and he examined the connection between blood relationships and conversion patterns. Shinto and Buddhism in Japan are closely connected with their cultural traditions such as harvest festivals or rites of ancestors. Moreover, they have functioned to strengthen their group ties. Sakano's study confirmed that the religion had two social functions to strengthen/weaken social networks among peo- 
ple in a local community. The latter indicates that Anglophone human geographers paid more attention to the processes of production and reproduction of religious places by social groups than have Japanese geographers. Therefore he tried to analyze the processes in which rural Buddhist buildings, especially New Buddhism's 'Dojo' (unofficial temples), have changed their forms and relations with social groups.

Concerning the relationship between new exploitation colony and the foundation of religion in the Meiji Era, Endo (2006) examined characteristics of the process of erecting shrines in militia settlement focusing on reciprocal relationships between the origin of shrine erection and the policies of the Meiji Government. Her point of argument is to consider both the political situation of the Meiji Government and the regional background of Hokkaido. She showed that the Meiji Government had been willing to organize the nation by centralizing power in the Emperor by symbolizing shrines as places of national ritual. The militia settlement had played an important role in improving the recognition of people as members of the Meiji Nation. In the case of Taniguchi (2004), she revealed the process of formation of communities in terms of the relationship between town planning and Christianity in Guelph, Southern Ontario. She concluded that the church buildings were very important for town planning in Guelph, therefore people sought closeness and consolation in religion whether they were Catholic or other protestant denominations. When the settlement moved from frontiers to urban centers, the process of establishment of religious groups played an important role for the people and their community.

Religious landscape is one of the important viewpoints when we consider religion and social groups. Nakagawa (1997) explored the landscapes of cemeteries, and discovered that there are differences by religions, race and regions. He showed that the landscapes of cemeteries are formed to express the identities of the group people belong to. Therefore we can recognize the perceptions of the group which constructed the cemeteries from these cultural landscapes.

Yamaguchi (1997) and Kawai (2001) applied the method of humanistic geography to the research of sacred places. Yamaguchi showed the structure of attractive landscapes of sacred places. Kawai regarded the Fujitsuka as a copy of Mt. Fuji, and tried to restore the landscapes of Mt. Fuji which the members of the Fuji-kou had viewed. Kawai (2004) suggested the method to reconstruct the sacred landscape from the view of social constructionism in her subsequent paper. Moreover, Kawai (2006) explained the symbolism of a religious association (Shun'nichi-kou) in the Edo period. She analyzed a sacred map (mandala) and a ritual conducted by Shun'nichi-kou. She explored Mikasa Mountain, a holy place for the members, drawn in mandala. In the map, leaves of trees on the mountain were drawn in bright green, because Gods were believed to be present. She concluded that they considered the sacred Mikasa Mountain had always been covered with bright green trees which symbolize the landscape of spring full of plant's energy.

Restoration of the religious landscapes was researched by Funasugi (1998), who treated the formation of the religious city (Monzenmachi) in Ise area at the Era of Sengoku, and Kaneko (1998), who explored the historical transition of mountain climbing routes in Mt. Iwaki. Tsugawa (1998) concluded a forward-looking research which deals with the establishment process of the Kannon statue. Religious landscapes have not yet been argued enough in Japan. Therefore this is one of the expectative themes in the geography of religion.

\section{Studies on Climate and Natural Environment}

There are some researches which treat the relationship between religion and natural environment such as topography and climate. Matsui (1995b) treated the faith in thunder, and found that the contents of faith are quite different in each place affected by the topographical conditions. Unagami (1996) showed the distribution of the Hikawa shrines in the Edo Era, and showed its relationship with rivers, lakes and marshes. Tagami (2000, 2001) dealt with the connection between wind festival and natural environment in Toyama Prefecture.

We can find some researches which explored the effects of faith in natural environment. 
Nagano (1995) showed the faith in mountains as a traditional spiritual culture in Japan, and showed that this faith contributes to the conservation of nature. Kanasaka (2001) introduced the landscapes of tutelary forest (Chinju) drawn in some paintings and maps. The tutelary forest was concerned as an important landscape of archetype. However there are not enough contributions from geography in comparison with ethnological and historical studies. From the view of macro scale, Kayane (2002) tried to demonstrate religious characteristics of Hinduism in the light of climate. He thought that Asian climate has a deep relation to sacred waters. As a natural scientist, he used rich fieldwork data to make clear the interrelation between natural environment and religious acculturation.

Taira (2002), who is a historian of religion, demonstrated the landscape and natural environment of sacred places in Okinawa, and interpreted the religious tradition in Okinawa. He pointed that Ojima, one of the sacred landforms in Okinawa, is located in the center of the pole which connects heaven, earth and underworld. Research of interpretations of religious worlds will contribute to considerations of environmental problems.

\section{Studies on Pilgrimage, Tourism and Sacred Place}

Although the theme of pilgrimage and tourism do not necessarily belong to the same category, the pilgrimage, a departure to a different/meaningful place with an important motive, has a close relation with tourism. On the theme of pilgrimage, Oda, M. and Tanaka, T. have been publishing many achievements from the 1980s. Oda (1995) took up the Catholic pilgrimage in southern Germany, and has reported the present condition from his experience. Besides Oda, Yokota (2007) showed some features of contemporary pilgrimage in Santiago de Compostela. They are precious reports of pilgrimage overseas which tends to be overlooked by Japanese geographers. Oda (2007) has elucidated pilgrimage routes in the Omine Mountains (Omine nyubu syugyo) in modern times with special reference to the prewar pilgrimage organized by Shogoin Temple. In his subsequent paper, he pointed out the travel routes before and after the mountaineering pilgrimage in analyzing the modern transportation facilities. As mentioned above, Tanaka (2004) made a great contribution to the actual condition of Japanese pilgrimage. He pointed out the foundation process of Saikoku pilgrimage route in the pre-modern era. He also showed a pilgrimage-related database, which is a very precious resource for researchers.

Iwahana (1999) has followed the change of religious mountain village from the viewpoint of tourism. He has considered the increase of restaurants and souvenir shops, and the transformation of the community at Chusya settlement in Mt. Togakushi. Similarly Matsui (1996) examined the functional change of a religious mountain with the development of tourism, by describing the cultural landscape of Shinobu Mountain as a tourist attraction, and how it would be utilized by people. Religious behavior of visiting shrines/temples has been affected deeply by tourism activity on the mass level. It is expected to become more important to analyze a religious phenomenon from the viewpoint of tourism.

Matsui (2005, 2006, 2007) explored and discussed the interrelation between reconstruction of sacred place and tourism. Referring to Shackley (2001), Matsui (2005) argued sacred sites as visitor attractions created in the modern world, and the importance of elucidating the process of how they were created and who managed those sites, and also considered the significance of sacred spaces. Shimazaki and Wagner (2005) also demonstrated some features of managing pilgrimage in the world. In the following articles, Matsui (2006) examined how religious historic cultures became the resources of modern tourism and how religious sacred spaces are constructed as tourist areas. He also tried to clarify the significance of this kind of local religious culture as a World Cultural Heritage movement (Matsui 2007). Recently, various entities such as local governments, tourism industries, tourists and hosts support this movement with the hope of social economic effects. Geographers of religion should observe the politics of these entities.

In this category, I would like to take note of a series of studies by Mori, M. (Mori 2001a, b, $2002 \mathrm{a}, \mathrm{b})$. Mori's framework is based on the "new 
cultural geography" and tried to clarify the relationship between religious phenomena and politics in Japan (Mori 2001a). Focusing on a Buddhist pilgrimage route identified by signs "Henro-michi" in Shikoku Island, he discussed that religious landscape and meanings have been built and obtained through various conflicts. For example, in 1960s and 70s, the value of pilgrimage route had been recognized as a cultural heritage and tourism resource by authorities. After that, it was rebuilt as a hiking course emphasizing the cultural value and excluding the religious meaning of the pilgrimage route. Mori (2002b) discussed the changing spatiality and movement modes of the "Henro" pilgrimage in Shikoku Island from 1920 to 1930 . He indicated that various agents like tourism, pilgrimage association, and most of all, the Japanese government had reconstituted the network in the space of "Henro" pilgrimage. Mori (2001b) also considered the process of how sacred space was created by Muroto City and the Buzan Sect of Shingon Buddhism since the 1970s. It is very important for geographers of religion to clarify the meaning of the sacred place from the connection with tourism, local government and religions. Furthermore, Mori (2005b) examined to explain how Kobo-Daishi, who is a founder of the Shingon-syu sect, was articulated with Japanese culture through exhibitions which were both organized and reported by the mass media and represented as a national hero.

Hara (2005) presented an interesting study of the relationship between pilgrimage and historical consciousness. He attempted to understand people's consciousness of Kamakura and the reality of pilgrimages to Kamakura, and examined a pilgrimage history from the view of intellectual satisfaction. Moreover, he tried to analyze the relationship of various forms of pilgrimages to Kamakura with the development of historical consciousness and the structural history of culture and intelligence. There were two types of visitors; one is "urban intellectuals" and the other is "upper class villagers". The former, having a high educational background, had developed a greater interest in a retrospective trend. On the other hand, the latter took a "simple trip" visiting major temples/shrines there.

As for the studies on the characteristics of sa- cred place, Onizuka $(1995,1996)$ sought the religious meaning of boundaries which have symbolic meaning in human life to elucidate the cosmology of living space in ancient Japan. She indicated that there was a place with religious meaning, in spite of its not being a religious institution, and that there existed various views of boundary. Noticing topographical meaning of junction (tsuji), Matsumoto (2004) argued spatial functions and religious meanings of tsuji.

\section{Recent Trend of the Geography of Religion in Japan}

As mentioned above, we can consider that the geography of religion in Japan is mainly seeking to analyze and interpret the distribution/diffusion of religious phenomenon including religious experience or practice, spatial structure of religion, and religious landscape. In this section, I will summarize the research trend of four fields.

The first type is the studies which focus on how a certain religion has been worshipped by people in urban or rural area. We have two analytical views in this type. One is focusing on propagandists and believers in order to understand the mechanism of distribution/diffusion of religions through examining the aspect of coexistence and competition among some religions in a certain community. We can see other studies which analyze religious diffusion in relation to external factors, such as the socioeconomic situation including regional network in that area. Both views are, without contradiction, trying to elucidate the relation between religion and region.

There have been many publications focusing on the study of the worship catchment area in recent decades (Matsui 1998; Kaneko 1995; Oda 2004). Having great interest in the spatial structure created by religion, these studies also demonstrated a deep interest in the diffusion of several beliefs. Kaneko (1995) indicated that many of them expressed more concern with elaborate regional division than with analyzing the dynamism of the worship catchment area.

The second type includes how religion influenced and played a role in the communities, as well as how it changed the cultural landscape in urban/rural area. Using the method of rural ge- 
ography, urban-social geography and historical geography, they mainly analyzed religious events and organizations of religion so as to elucidate geographical characteristics of rural area. As the studies on religious cities and religious settlements in the mountain have been decreasing, we can not easily find research analyzing the relationship between religion and rural area (Oda 2002). On the contrary, there have been a lot of contributions on the impact of religion on the landscape (Matsui 1993). It is desirable that studies on landscape should also focus on the believer's individuality and the meaning for themselves, which can be carried out in studies of the interpretation of the sacred landscape and symbolism (Kawai 2004 and so on).

The third field encompasses achievements of religious ecology and relationship with natural environment. One of the important purposes of the geography of religion is to clarify the relationship between the environment and religious phenomena (Kong 1990). Since religious phenomena inevitably appear in historical phenomena, it is important for geographers of religion to understand the natural environment surrounding the religion. While religion is closely related to nature, religion itself has affected nature at the same time. However, there are few studies of the influence of religion upon the natural environment. Nagano (1995) is a valuable paper to pursue the role of religion in the conservation of nature and preservation of the environment.

Lastly, studies on pilgrimage have revealed the socioeconomic network produced by religion in the field of historical geography. Moreover, since pilgrimage studies are increasing after the 1980s (Oda 2002) and have an affinity with tourism, especially from the view of political and social background, the studies of pilgrimage route in the present day and the creation of religious landscape have appeared under the influence of new cultural geography. Now, we need to ask how the sacred place is produced by various conflicts among different subjects.

\section{Towards the New Geography of Religion}

Park (1994) has tried to review extensively about the geography and religion after the 1960s. He showed us these six themes; 1) spatial pat- tern of religion, 2) diffusion of religion, 3) dynamics of religion, 4) religion and demography, 5) religion and landscape, and 6) sacred sites and pilgrimage. There are some themes which the Japanese geographers of religion have not discussed, which Western geographers focus on: "ethnicity and religion" and "religion and politics". These themes are categorized into 4) in this book. In Japan, however, sociologists of religion have keen concern for these areas. Manifestation of religious phenomena is so various that study fields relevant to religion are also diversified. Oda (2005) proposed three main issues as the prospects of this field. First, Japanese geographers of religion should ask how and why religions have been distributed in cooperation with the historians of religions. Second, they should elucidate how Japanese religions control environmental modification. Third, they are requested to grasp religious phenomena in light of social, economic and political situations in the regions. Now that many human and social sciences are also losing their borders, it will be more difficult to find the positive meaning of categorizing studies as well as distinguishing the boundary of the geography of religion from other studies. Moreover, it is requested that we, geographers, have to bridge the interdisciplinary field at the same time.

As concluding remarks, I will take up some subjects of the geography of religion in the near future. First of all, the geography of religion should contribute more to the elucidation of the religion. Park (1994) distinguishes two approaches of the geography of religion; one is the "religious geography" focusing on the role of religion in the formation of worldview or place recognition of human beings, and the other is "geography of religion" having much concern to the relationship with society, culture and environment. He noted that many scholars have had more concern to the geography of religion than religious geography. This is also affected by the stance as to whether he/she recognizes the geography of religion as a part of geography or a part of religious studies. I think that the studies which are conscious of being religious studies need to be produced from geography, as much as cultural geography tends to strengthen the character of cultural studies. I would expect the 
development of religious studies to be based on the characteristic of geography. Nakagawa (2005) discussed that the modern geography had discarded teleology and regional substantialism. He clarified that religious values based on teleological cosmology have actually created regional communities through their behavior. We will get more publications examining religious thought and sacredness considered to be able to influence individuals, societies and spaces directly, or examining the direct influence of religious thought and sacredness on individuals, societies, and spaces (Fujimura 2006: 74).

Secondly, researchers in this study field are requested to focus on the religious situations in modern Japan. In the last decade, contributions by historical geographers have been remarkable. On the other hand, geographers should now pursue themes elucidating the modern religious situation in Japan including social problems of new religion, symbolism of religious buildings and relationship between tourism and religion.

Thirdly, studies considering the religious characteristics of Japan are demanded. It is possible to say that Japan is a religious laboratory (Kishimoto 1961), and one of the important features of Japanese religions is syncretism (Shimazono 1987). In Japan, since various religions like Shinto, Buddhism and other folk religion coexist without inconsistency in the community, it could be said to be a good study field for the geography of religion.

Oda (2004) indicates three subjects in the historical geography of religion as follows: 1) to ask how and why religions have been distributed in cooperation with the historians of religion; 2) to clarify how Japanese religions interpret environmental modification; and 3) to grasp religious phenomena in the light of social, economic and political situations of the religion. Suzuki (2004) also commented that we need various key notions of cultural studies when we consider the concept of space, such as function and structure, surface and depth, significance and signification, representation and discourse, and text and performance, and insists that these conceptions should apply to the studies of the geography of religion. Recognizing the importance of both indications, the well-laid foundations of research are well demonstrated in this paper. Empirical studies on religion and geography have been accumulated through the $20^{\text {th }}$ century. We now have to start to construct systematization and theorizing based upon these empirical studies. It is expected that the geography of religion in the $21^{\text {st }}$ century will grow to play more important role in geography in Japan.

\section{Acknowledgments}

I gratefully acknowledge Dr. Waldichuk, T. in the Thompson Rivers University for his critical comments. This study was supported by Grants-in-Aid for Scientific Research by JSPS(A)19202027, (B) 18320018, (C) 18520611 .

(Received 29 August 2007)

(Accepted 30 January 2008)

\section{References}

Endo, Y. 2006. A study of establishing shrines and the patterns in the militia settlement-Focusing on the middle and upper area at the Ishikari River, Hokkaido, Japan-. Historical Geography 48(5): 1-18. (JE)

Fujimura, K. 2001. Religious diversity and its factor in a village of Oku-kumano. Historical Geography 43(5): 21-37. (J)

Fujimura, K. 2004. The transition of relations between Shin Buddhism's 'Dojos' and village societies: Case studies of two villages in Echizen Province. Historical Geography 46(1): 1-14. (JE)

Fujimura, K. 2006. Problems with essentialism and constructionism in contemporary geographical studies of religion. Geographical Review of Japan 79: 251-263.

Funasugi, R. 1994. Kinseiki chichibu ni okeru ise shinko no tenkai (Characteristics of Ise shrine worship around Chichibu in the Edo Era). Area Research Report of Historical Geography 6: 5765. (J)

Funasugi, R. 1997. Infiltration of Ise shrine worship in the Sengoku Period and its background: The case of Izumoda-no-sho in Kambara district, Echigo Province. Geographical Review of Japan 70A: 491-511. (JE)

Funasugi, R. 1998. Formation process of a religious town, Yamada, around Geku of Ise shrine in the Sengoku Period: The case of Kami-no-go area. Historical Geography 40(3): 1-22. (JE)

Hara, J. 2005. Pilgrimage and historical consciousness in the early modern age: Rediscovery of Kamakura and a retrospectivism. Historical Geography 
47(3): 1-23. (JE)

Hiromoto, S. 2004. Distribution of the belief of Hakuyusan/Takayu-san in the Nasu Mountains. Historical Geography 46(1): 15-31. (JE)

Hisatake, T. 2000. Bunka-chirigaku no keifu (Genealogy of cultural geography). Kyoto: Chijinshobo. (J)

Imamoto, A. 2000. The formation of small social groups in a village and social unity of the smallest unitarea: A case study of Kawanami, Shiga Prefecture. Human Geography 52: 173-189. (JE)

Imazato, S. 1995. Rural religious landscape constituents and social structure: A case study of a mountain village, Shiga Prefecture. Human Geography 47: 458-480. (JE)

Inoue, N. 2002. Shukyo-shakaigaku no susume (Intoroduction to the sociology of religion). Tokyo: Maruzen. (J)

Ishida, Y. 1989. Shukyogaku no tenbou (Prospect for the study of religion). In Shukyougaku o manabu hito no tameni (Introduction to the learners of religious studies), ed. Y. Ishida and T. Sonoda, 206-222. Kyoto: Sekai-shisou-sha. (J)

Iwahana, M. 1997. Results and themes of the Tateyama mandala research. Japanese Mountain Religion 20: $15-20$. (J)

Iwahana, M. 1999. Recent changes of the recreational activities in a mountain religious village of Togakushi, Third report. Quaterly Jounal of Geography 51: 19-27. (JE)

Iwahana, M. 2000. Tabi no ikuukan-Chirigaku to minzokugaku no aida-(Review of religious tourism in terms of geography and folklore). Yamagata Folklore 14: 114-128. (J)

Iwahana, M. 2003. Dewasanzan shinko no kenkouzou (Zonal structure of Dewa Mountains). Tokyo: Iwata-shoin. (J)

Kanasaka, K. 2001. Ezu, chizu ni arawareta chinju no mori (Landscape of tutelary forest depicted in pictorial maps). In Chinju no mori wa yomigaeru (Revival of tutelary forest), ed. M. Ueda and A. Ueda, 107-132. Kyoto: Shibunkaku-shuppan. (J)

Kaneko, N. 1995. A Review of studies on the spatial structure of mountain religion in Japan. Humanities Review 45(3): 104-117. (J)

Kaneko, N. 1998. Historical change of pilgrimage routes climbing up to Mt. Iwaki. Historical Geography 40(5): 22-42. (JE)

Kawai, Y. 2001. Mt. Fuji as a sacred site: On historical change in Fuji-kou and Fuji-zuka in the 23 wards of Tokyo. Geographical Review of Japan 74A: 349-366. (JE)

Kawai, Y. 2004. The method to reconstruct "the sacred landscape" constructed by the social community.
Historical Geography 46(1): 50-64. (JE)

Kawai, Y. 2006. The sacred landscape of Shun'nichikou in Machi of Nara in the Edo Period: Analysis of a sacred map, Mandala of Shun'nichi, and its ritual. Japanese Journal of Human Geography 58: 181-196. (JE)

Kayane, I. 2002. Mizu to megami no huudo (Climate and goddess). Tokyo: Kokon-shoin.(J)

Kishimoto, H. 1961. Shukyogaku (Science of religion). Tokyo: Taimeido. (J)

Kong, L. 1990. Geography and religion: Trends and prospects. Progress in Human Geography 14: 355-371.

Matsui, K. 1993. Development of geography of religion in Japan. Human Geography 45: 515-533. (JE)

Matsui, K. 1995a. The sphere of religion of Kasama inari shrine classified by distributions of believers. Geographical Review of Japan 68A: 345-366. (JE)

Matsui, K. 1995b. A regional study of the sphere of religion of Kanamura betsurai shrine. Journal of Religious Studies 69: 177-209. (JE)

Matsui, K. 1996. A study of tourism resources and utilization in Shinobu mountains. Journal of Tourism Research 29: 91-101. (JE)

Matsui, K. 1998. Reexamination of recent studies on the geography of religion in Japan. Annual Report of Institute of Geoscience, University of Tsukuba 24: 7-13.

Matsui, K. 1999. Regional characteristics of the belief in the Kanamura Betsurai shrine between the inner and outer areas. Geographical Review of Japan 72B: 1-22.

Matsui, K. 2003. Nihon no shukyo kukan (Religious spaces in Japan). Tokyo: Kokon-shoin. (J)

Matsui, K. 2005. Problems of managing sacred sites in terms of tourism: A conflict between religion and tourism. Tsukuba Studies in Human Geography 29: 147-179. (JE)

Matsui, K. 2006. "Christian" as a tourism strategy. Tsukuba Studies in Human Geography 30: 177209. (JE)

Matsui, K. 2007. The gaze for local-religious culture in a World Heritage movement. Tsukuba Studies in Human Geography 31: 133-158. (JE)

Matsumoto, T. 2004. On the spatial function and the religious meaning of the places on the junction of the three planned roads in pre-modern upper Sagami. Historical Geography 46(1): 65-78. (JE)

Miki, K. 1996. Development of the cult of Mitsumine in the Chichibu region, particularly in relation to forest felling. Geographical Review of Japan 69A: 921-941. (JE)

Miki, K. 1998. Religious groups and their regional back- 
ground in a mountain village: A case of Ohno Village, Chichibu district, in the Edo Era. Historical Geography 40(2): 2-21. (JE)

Miki, K. 2001. The cult of Mitsumine in Edo: Its development and social background. Human Geography 53: 1-17. (JE)

Miki, K. 2005. The development of the cult of Mitsumine in the Kanto Plains, with the particular focus on the east Musashi Province. Annual Report of the Faculty of Education, Bunkyo University 39: 63-77. (J)

Mori, M. 2001a. Contemporary religious meaning of the pilgrimage route. Human Geography 53: 173189. (JE)

Mori, M. 2001b. Authenticity and sacredness of place. Geographical Sciences 56: 252-271. (JE)

Mori, M. 2002a. Representing and consuming Henro pilgrimage on Shikoku island. Humanities Review 51(4): 160-173. (J)

Mori, M. 2002b. Spatial formation and change in the Henro pilgrimage in modern Japan. Human Geography 54: 535-556. (JE)

Mori, M. 2005a. Shikoku henro no kingendai (Modern times of the Shikoku pilgrimage). Osaka: Sogensha. (J)

Mori, M. 2005b. Reviving nationalism by articulation of the priest Kobo-Daishi and Japanese culture in 1934 exhibitions. Geographical Review of Japan 78: 1-27. (JE)

Nagano, T. 1995. The mountain belief of Japanese people and its nature conservation. Journal of the Geographical Society of Hosei University 23: 3-18. (J)

Nakagawa, T. 1997. Louisiana no bochi: Shi no keikan chirigaku (Louisiana cemeteries). Tokyo: Kokon-shoin. (J)

Nakagawa, T. 2005. Spiritual mapping no rironka ni kansuru shukyo chirigakuteki kenkyu (Geographical study of religion about theorization on spiritual mapping). Tsu: Faculty of Humanities and Social Sciences, Mie University. (J)

Oda, M. 1995. Catholic pilgrimage in the southern part of Germany: Some cases in the thousandth anniversary of the death of Saint Wolfgang. Komazawa Geography 31: 39-68. (JE)

Oda, M. 1999a. Geography of religion in Japan since 1977. Regional Views 12: 27-32.

Oda, M. 1999b. Distribution of Christianity in Japan. Pennsylvania Geographer 37(1): 17-32.

Oda, M. 2002. Geography of religion in postwar Japan: An analysis of the bibliography. Komazawa Geography 38: 21-51. (JE)

Oda, M. 2003. Distribution of Buddhism in Japan: An attempt to draw a map of the Buddhist-denomi- national regions. Komazawa Geography 39: 3758. (JE)

Oda, M. 2004. Geographical themes in the study of worship catchment area-A review of religious space of Japan by Keisuke Matsui-. Komazawa Journal of Geography 40: 105-120. (JE)

Oda, M. 2005. Conclusion: Future issues in historical geography of religion culture. Historical Geography 47(1): 107-110. (JE)

Oda, M. 2006. Distribution of Buddhist denomination in Japan. Regional Views 19: 31-36.

Oda, M. 2007. Travel routes before and after the mountaineering in prewar pilgrimage in the Omine mountains. Komazawa Geography 43: 19-38. (JE)

Onizuka, K. 1995. Relationship between religious places and boundaries in ancient palace cities and provincial capitals. Human Geography 47: 1-20. (JE)

Onizuka, K. 1996. A study of ancient religious places and Jinmen-bokusyo ware. Historical Geography 38(5): 19-37. (JE)

Otsuka, M. 1997. Syncretism of Onbashira festival in the Suwa area. Annual Bulletin of the Institute of Humanistic Sciences, Rissyo University. Special Publication 11: 30-48. (J)

Park, C. 1994. Sacred worlds. New York: Routledge.

Sakano, Y. 2003. The distribution and development of the religious worship of Mt. Hakkaisan. Historical Geography 45(5): 1-18. (JE)

Sakano, Y. 2006. Conversion to the Catholic religion of rural society in postwar Japan: A case of group conversion in Saga village, Kyoto. Japanese Journal of Human Geography 58: 357-376. (JE)

Shackley, M. 2001. Managing sacred sites: Service provision and visitor experience. London: Coninuum.

Shimazaki, H., and Wagner, P. L., 2005. Managing pilgrimage. Japanese Journal of Human Geography 57: 195-205.

Shimazono, S. 1987. Shugo-shukyo (Syncretism). In Minkanshinko chosa seiri handobukku (Handbook of the survey method folk religion), ed. F. Tamamuro, E. Hirano, H. Miyake and N. Miyata, 169-181. Tokyo:Yuzankaku-shuppan. (J)

Suzuki, M. 2005. Comments on the whole symposium II. Historical Geography 47(1): 102-106. (J)

Tagami, Y. 2000. "Kazamatsuri" and "Kazakama" around Toyama Prefecture. Bulletin of the Faculty of Education Toyama University 3: 69-82. (JE)

Tagami, Y. 2001. Distribution of "Kazenomiya" around Toyama plain and its related factors. Bulletin of the Faculty of Education Toyama University 4: 13-28. (JE) 
Tagami, Y. 2002. Some characteristics of shrine distribution in central Japan. Geographical Reports of Tokyo Metropolitan University 37: 51-60.

Taima, S. 1961. Nihon shukyo-chirigaku no teisho (Advocacy on the religious geography of Japan). Human Geography 13: 347-360. (J)

Taira, S. 2002. The "Landscape" and the Imago Mundi: Reinterpretation of the sacred landscape of "Ou" in Okinawa Island. Studies in Philosophy 27: 131-151. (JE)

Takemura, K. 2000. A geographical study on the acceptance of the mission of the Church of Jesus Christ of Latter-day Saints in the provincial cities of Japan. Geographical Review of Japan 73A: 182-198. (JE)

Tanaka, T. 2004. Seichi o meguru hito to michi. (Pilgrims and routes around sacred places). Tokyo: Iwata-shoin. (J)

Taniguchi, M. 2004. Town planning and Christianity during the nineteenth century in Guelph, Southern Ontario. Historical Geography 46(5): 1-14. (JE)

Tsugawa, Y. 1998. A study of religious landmark. The Journal of Ritsumeikan Geographical Society 10: 49-58. (J)

Tsutsui, Y. 1999. The spatial structure of religious zone by the distribution of regional groups (Kochu) registered to Taiheizan-Miyoshi-Shrine in Akita Prefecture. Geographical Review of Akita University 46: 27-32. (J)

Tsutsui, Y. 2001. A geographical study on religious areas: the case of Chokaisan-Omonoimi-Shrine. Geographical Review of Akita University 48: $1-8 .(\mathrm{J})$

Tsutsui, Y. 2004. The formation of believers' group 'Chokai-ko' in the religious area of OhmonoimiShrine. Historical Geography 46(1): 32-49. (JE)

Unagami, N. 1996. An analysis on the Hikawa jinja on the basis of a geographical method: Around underlying belief. Journal of the Graduate School of Humanities 4: 43-94. (J)

Yagi, Y. 1998. Minzoku sonraku no kukan kouzou (The spatial structure of folk village). Tokyo: Iwata-shoin. (J)

Yamaguchi, Y. 1997. Landscape structure of a sacred basin village, Muro: Paying attention to a landscape attracting human beings. Human Geography 49: 159-174. (JE)

Yokota, N. 2007. Contemporary pilgrimage in Santiago de Compostela. Humanities Review 57(2): 53-72. (J)

$(\mathrm{J})$ : written in Japanese

(JE): written in Japanese with English abstract 